\title{
Empowerment Analysis of Crafts Slap Mendong in Blayu Village Malang Regency Indonesia
}

\author{
Rudianto $^{1} \&$ Tri Djoko Lelono ${ }^{1}$ \\ ${ }^{1}$ Faculty of Fishery and Marine Science, University of Brawijaya, Malang, Indonesia \\ Correspondence: Rudianto, Faculty of Fishery and Marine Science, University of Brawijaya, Malang 65145, \\ Indonesia. E-mail: hrudianto@ub.ac.id; haji_rudianto@yahoo.com
}

Received: December 12, 2014 Accepted: January 21, 2015 Online Published: March 30, 2015

doi:10.5539/ep.v4n2p32 URL: http://dx.doi.org/10.5539/ep.v4n2p32

\begin{abstract}
Mendong plant is an aquatic plant with the Latin name Fimbristylis glubolusa. Such plants is used by Blayu residents as raw materials for making bags, lamp shades, hats, mats, bags. The problem faced by many craftsmen slap mendong in Blayu village is a lack of infrastructure, education, training capacity, competitiveness, and capital. Partial Least Square is used to analysis empowerment craftsmen. Its results the expertise and experience variables (X1) has a total effect of -0.198 , Variable Capital (X2) 0.896 , and the motivation variable (X3) 0.158 . This indicates that the variable capital (X2) has the strongest effect against Welfare (Y2).
\end{abstract}

Keywords: aid equipment, the craftsmen slap Mendong, partial least square

\section{Introduction}

As was the case in the last two decades, at least two major financial crisis occurs, i.e financial crisis in East Asia in 1997 and global financial crisis in 2008. If the crisis in 1997 caused by lack of transparency and credibility of the Government which caused structural distortions and policy (Corsetti et al., 1999). the economic turmoil of 2008 was mainly triggered by the rapid innovation in financial products such as the practice of securitization and credit default swaps. This is exacerbated by speculation of property and inaccurate credit ratings. On the both cases, the development of crisis has been spread to other continents in the short times. At this moment, global integrated financial systems become a burden for developing countries. (Arisyi F. et al., 2012).

Micro business has a strategic role in the development of national economy, the effect of which is the people's business is instrumental in economic growth and employment also play a role in distributing the fruits of development. Micro enterprises, which are surprisingly able to survive in times of crisis of 1997/1998, are the basis of the people's business,. This was due to the financial structure of micro-enterprises that are not much dependent on the banking. Although they still take advantage of banking services, both for transactions and for security reason. At that time a great deal of effort lying, bankrupt along with the bitterness of the crisis.

One potential agro-industrial centers to be developed in Malang regency is the center of agro industrial crafts slap Mendong located in District Wajak, especially in Blayu village. Mendong (Fimbristylis globulosa) is a family of cperaceae classified as pseudo grass (herb) were plated and can adapt to a puddle of water during the rainy season. Mina mendong farming is an agricultural activity which combines fish farming with crop cultivation in the rice fields mendong. It is very beneficial because it can produce two harvesting such as fish and mendong. Mendong has several advantages such as resistance to water and could not be eaten by pests such as termites.

Mendong that has flaked can be used for the manufacture of woven handicrafts and other craft businesses, such as wicker crafting mats, hats, ropes, bags, wallets and others. Craft production business rushes a hereditary business carried on by a resident in the study area. At the beginning the production process is a way to weave mats. However, today's craftsmen have used the weaving process to produce slap Mendong.

Hikmasari et al (2013) mentioned that productivity of farmers in the village of mina mendong Blayu and Wajak is still low. This is presumably because the farmers are not efficient in the use of production factors. Whereas, Fatih et al (2010) stated that The development of the center of Mendong Handicraft agro-industry in Malang Regency is facing some constraints like lack of infrastructure, education and training capacity, function of institution, specialization and competitiveness, and wholesaler domination. Facing such problems above. Based 
on the last observation in the area of mendong growth, the land conversion is becoming intensively change, from mendong land to settlements. Although, the value of land is economically feasible for growing mendong, the owner of mendong land tend to sell their land for settlements. Seitte (2012) stated that the cost of farming per hectare per mina mendong season of Rp. 3,508,135. with revenue of Rp. 15,472,707. and farm income of Rp. 11,964,572. Beside, mendong farm costs per hectare per cropping season of Rp. 2,365,392. with revenue of Rp. 10,155,471. and farm income of Rp. 7,790,079.

To face such problems, Many craftsmen slap mendong create joint business group called KUB in 2011. There are only 1 joint business group in Blayu village dan one joint business group in Kidangbang in one Wajak sub district area. In its operation KUB both in Blayu and Kidangbang empower each of their members to jointly maintain productions and innovations. Based on the above problems, the objective of this study is to to know the significance relationship among variables such as variables expertise and experience against welfare, variables capital against welfare, and variables motivation against productivity and welfare.

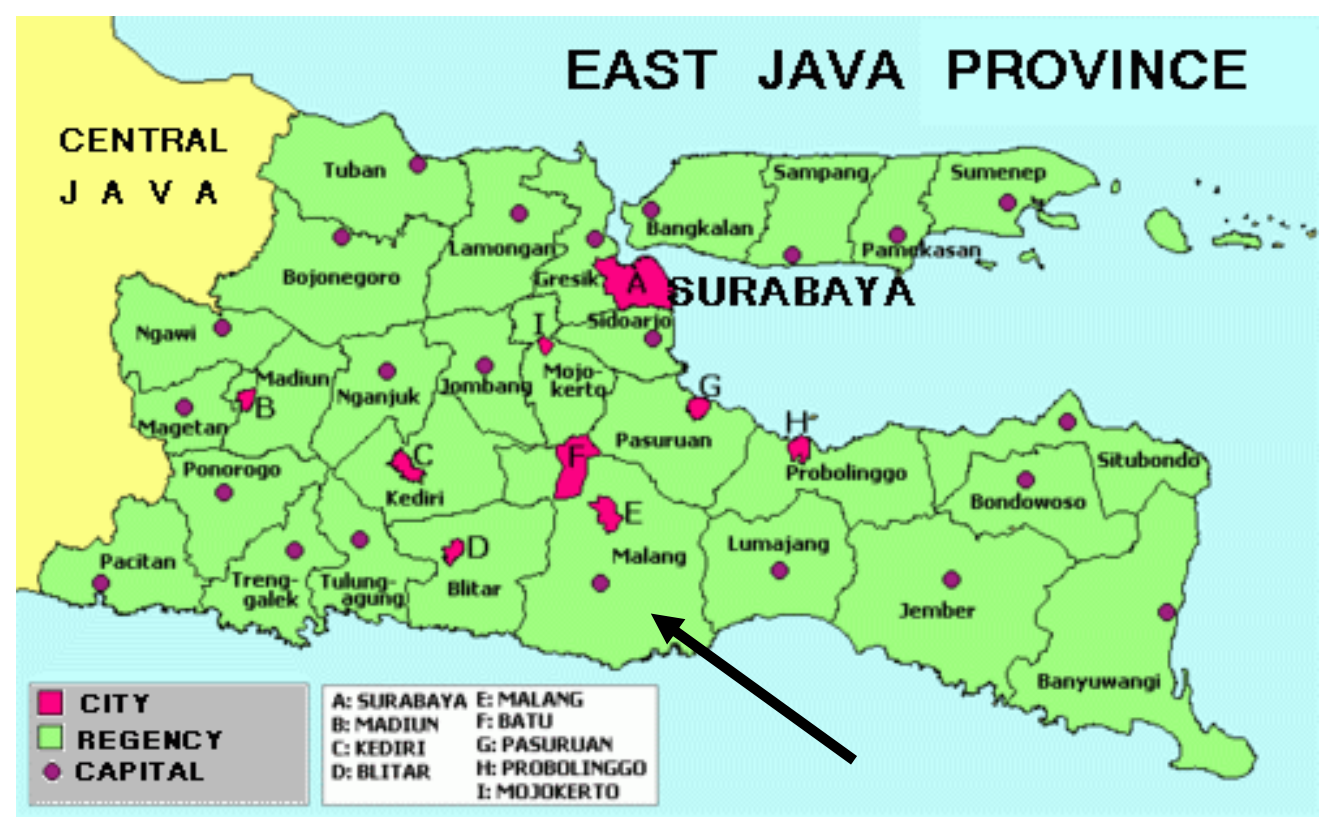

Figure 1. Map of Blayu village in Malang Regency East Java Province, Indonesia

\section{Materials and Methods}

The approach used in this study is a quantitative approach (positivism). A quantitative approach is used to measure the extent of expertise and experience, capital, and provide motivation effect on productivity and well-being craftsmen slap mendong. The approach uses statistical analysis to answer questions or testing of the hypothesis proposed. To operate above variables, it is needed conceptual model, which related with a descriptive model or diagram that shows the key elements in the system of interest and the hypothesized relationships between them. To provide a clear picture of its relation of those variables, it can be seen Figure 2 below. 


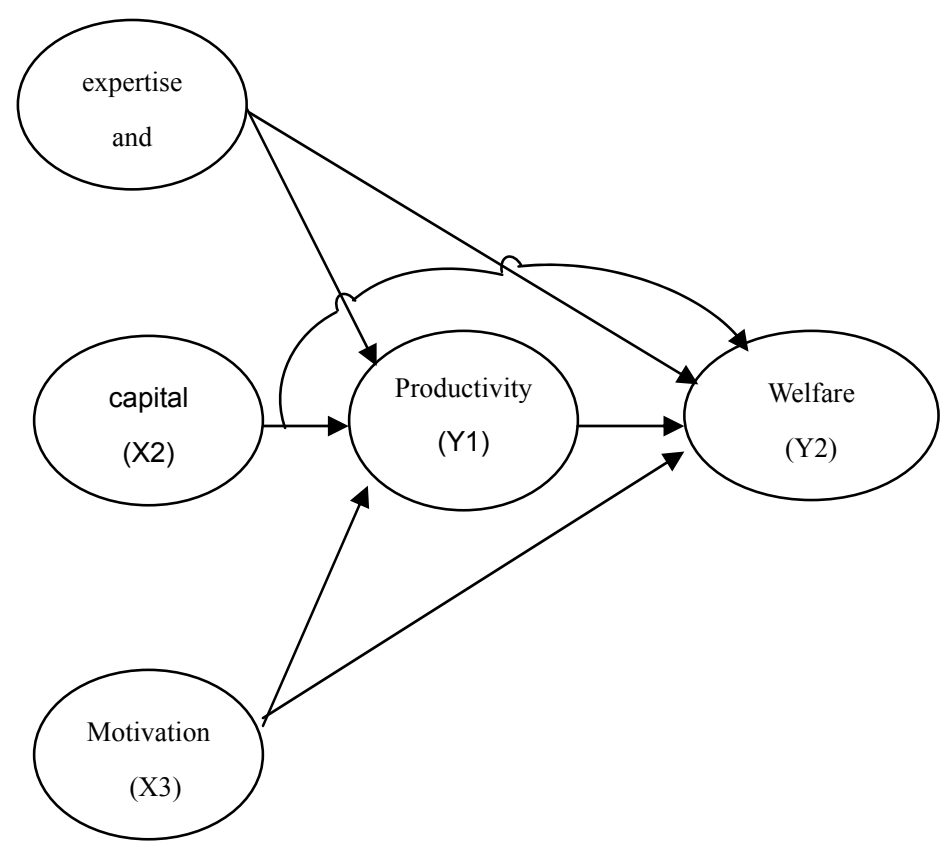

Figure 2. Conceptual model

Conceptual model above shows that productivity of craftsmen slap mendong affect three variables i,e expertise and experience, capital and motivation. Whereas, productivity will affect welfare. Table 1 below show the relationship among variables. The basic concept to build such model is related with human capital. Since long time economists recognised that human capital is an important part of the wealth of nations (Cabrita and Bontis 2008). There is significant relationship between human capital efficiency and financial performance (Maditinos, et al., 2011). Human capital has a significant effect on economic performance (Rafiei et al., 2011). Human capital is one of the most important parts of intellectual assets in an organization (Hajiha \& Hasanloo, 2011).

Table 1. Relationship among variables

\begin{tabular}{ll}
\hline \multicolumn{1}{c}{ Variables } & \multicolumn{1}{c}{ Indicator } \\
\hline Expertise and Experience(X1) & $\begin{array}{l}\text { Long been the member of the group } \\
\text { Participation in training } \\
\text { Long time producing slap mendong } \\
\text { Equipment } \\
\text { Cost }\end{array}$ \\
Motivation (X3) & $\begin{array}{l}\text { Background to produce slap mendong } \\
\text { The profit obtained as member of the group } \\
\text { The average quantity of production result In 1 time production } \\
\text { Productivity (Y1) }\end{array}$ \\
& $\begin{array}{l}\text { The duration of the completion of slap Mendong craft } \\
\text { Average income per weeks }\end{array}$ \\
\hline
\end{tabular}

The above diagram shows that independence variables as well as mediator and dependence variables are connect each others with variables tested among one variable and another. Such connections variables are expertise and experience (X1), capital (X2) and motivation (X3). They are called as independence variables. Productivity variables (Y1) as mediation variable and welfare as dependence variable. 


\section{Methods of Data Analysis}

This research is used testing measurement model based on reflective unidimensional construct. Hartono and Abdillah (2009) explain that unidimensional construct is construct created from indicators not only reflective but formative. To analyse this research, it uses a few of hypothesis by using Partial Least Square (PLS). They are as follows:

\subsection{Evaluation Outer Model (Measurement Model)}

A concept and research model could not be tested in a prediction model relationship between relation and causal, if they are not already passed the stage of purification in the measurement model. It can be used to scrutinize the construct validity and instrument reliability. The validity of a test is done to find out the capabilities of the research instrument measuring what it is supposed to be measured (Cooper and Schindler, 2006 in Hartono Abdillah 2009). Instead, the reliability test is used to measure the consistency of measurement tool in measuring a concept or it can also be used to measure the consistency of respondents in answering each item of questions or research instrument. The concept of test validity and reliability in this study can be explained as follows:

\subsubsection{Test Validity}

Validity indicates how well the results obtained from the use of an appropriate measurement theories used to define a variable. Validity is consisted of two factors. They are convergent and discriminant validity. Convergent validity is occurred, if the score obtained from two different instruments that measure the same variable has high correlation. Whereas discriminant validity is occurred, when two different instruments that measure two variables are correlated and do not produce the predicted score. (Hartono and Abdillah, 2009). Another method that is used to assess the validity of the discriminant is that to compare AVE (Average Variance Extracted ) root for any constructs with the correlation among constructs with construct in model. Such model has enough discriminant validity, if AVE root for every construct is higher that correlation among construct in model (Chin, 1997 in Hartono dan Abdillah, 2009). The table below shows the tabulation of validity test in PLS.

Table 2. Parameter test of the validity of the measurement in PLS model

\begin{tabular}{lll}
\hline Validity Test & \multicolumn{1}{c}{ Parameter } & \multicolumn{1}{c}{ Rule of Thumbs } \\
\hline \multirow{3}{*}{ Convergent } & Loading Factor & More than 0,7 \\
& Average Variance Extracted (AVE) & More than 0,5 \\
& Communality & More than 0,5 \\
\multirow{2}{*}{ Discriminant } & AVE root and laten variable correlation & AVE root $>$ Laten variable correlation \\
& Cross Loading & More than 0,7 in one variable \\
\hline
\end{tabular}

Sources: Hartono dan Abdillah (2009:61)

\subsubsection{Reliability Test}

This test to show accuracy, consistency of measurement tool in conducting the measurement. (Hartono and Abdillah 2009). In PLS, such kind of test could be conducted by using two methods, they are consisted of cronbach's alpha and composite realibility. Cronbach's alpha is measured lower limit of reliability a variable and it is said reliable if the value is more than 0,6 . Composite reliability is measured actual value of variable. This method is better than doing estimation of internal consistency a variable and it is said reliable if its value more than 0,7 .

\subsection{Evaluation Inner Model (Structural Model)}

Structural model in PLS is evaluated by using $\mathrm{R}^{2}$ for dependence construct. Coefficient path or $t$-values in every path for significance test among construct in structural model. Detail evaluation in this research can be explained as follows: Using $R^{2}$ and coefficient value. $R^{2}$ value is used to measure the level of variation changes of independence variable against independence variable. The highest $R^{2}$ means the better of prediction models from research model proposed. However such model is not absolute parameters to measure accuracy of prediction model. (Hartono dan Abdillah 2009). By using coefficient value path or t-values every path to test significant between variables in structural model. In this model will be used to show significance level in hypothesis test. To test hypothesis on alpha 5 percent and power 80 percent, if coefficient path value is showed by statistic value (T-statistic) $\geq 1,96$. Alternative hypothesis could be supported. (Hartono dan Abdillah 2009). 


\section{Results and Discussion}

Testing of validity and reliability research variables by Examinations of latent variable of validity can be approached from AVE value, composite reliability and cronbach alpha coefficient. When convergent validity is comply with AVE value, then value has AVE more than 0.5. Whereas research instrument has an internal consistency, if composite reliability value as well as alpha cronbach has value more than 0,6 and 0,7 . approached from AVE value, composite reliability and cronbach alpha coefficient. Convergent validity can be fulfilled if AVE value more than 0.5 . While, the research instrument is said to have a good internal consistency if the value of Cronbach alpha compositing reliability and successively greater than 0.7 and 0.6. Following the results of testing the validity and reliability of each latent variable:

Table 3. Validity and reliability testing of latent variables

\begin{tabular}{lcccc}
\hline Variable & AVE & Communality & Composite Reliability & Alpha Cronbach \\
\hline Expertise and experience & 0.795 & 0.795 & 0.920 & 0.863 \\
Capital & 0.962 & 0.962 & 0.981 & 0.960 \\
Motivation & 0.836 & 0.836 & 0.910 & 0.826 \\
Productivity & 0.987 & 0.987 & 0.993 & 0.987 \\
Welfare & 1 & 1 & 1 & 1 \\
\hline
\end{tabular}

Based on table 3 above, it can be explained that research instrument used is valid and reliable. Goodness of Fit structural Model (Inner Model). Goodness of Fit of structural in inner model is used predictive-relevance $\left(\mathrm{Q}^{2}\right)$ value. Following the result of predictive-relevance $\left(\mathrm{Q}^{2}\right)$ structural model as follows:

Table 4. Goodness of fit model $\left(\mathrm{R}^{2}\right.$ dan $\left.\mathrm{Q}^{2}\right)$

\begin{tabular}{rrrr}
\hline & Endogen Variable & $\mathrm{R}^{2}$ & $\mathrm{Q}^{2}$ \\
\hline & Productivity (Y1) & 0,086 & 0,883 \\
Welfare (Y2) & 0,872 & \\
\hline $\mathrm{Q}^{2}$ & $=1-\left(1-\mathrm{R}_{1}{ }^{2}\right)\left(1-\mathrm{R}_{2}{ }^{2}\right)$ & & \\
$\mathrm{Q}^{2}$ & $=1-(1-0,086)(1-0,872)$ & & \\
& $=0,883$
\end{tabular}

The calculation result shows the predictive value-relevance (Q2) of 0,883 or $88,3 \%$. Predictive value of relevance $88,3 \%$ indicated that the diversity of data can be explained by the model was of $88,3 \%$. While the rest $11.7 \%$ can be explained by another variable that it cannot be include in model and error.

Outer loading can be used to know the contribution of indicators as measure latent variable. The value of the outer large loading gauge degrees of latent variables shows a strong and vice versa. The value of the outer large loading gauge degrees of latent variables shows a strong and vice versa.Based on SmartPLS output the result of outer loading can be explained as follows : 
Table 5. Testing the outer structural model

\begin{tabular}{cccccc}
\hline Latent Variable & Indicator & Outer Loading & T-Statistic & P-Value & Remarks \\
\hline \multirow{3}{*}{ Expertise and experience (X1) } & x1.1 & 0.967 & 44.451 & 0.000 & Most Powerful \\
& x1.2 & 0.717 & 10.015 & 0.000 & \\
Capital (X2) & x1.3 & 0.967 & 44.451 & 0.000 & Most Powerful \\
& x2.1 & 0.982 & 594.772 & 0.000 & Most Powerful \\
Motivation (X3) & x2.2 & 0.979 & 503.566 & 0.000 & \\
Productivity (Y1) & x3.1 & 0.855 & 7.555 & 0.000 & \\
Welfare (Y2) & x3.2 & 0.970 & 8.256 & 0.000 & Most Powerful \\
& $\mathrm{y} 1.1$ & 0.994 & 699.668 & 0.000 & Most Powerful \\
& $\mathrm{y} 1.2$ & 0.993 & 799.346 & 0.000 & \\
\hline
\end{tabular}

Based on table 5 above, it can be explained that all indicators of expertise and experience (X1) has p-value less than 0,05 . This indicates that invalid constructs a variable skill and experience (X 1) significantly. Old indicators became a member of the Group (x 1.1) and long time to produce slap mendong (x1.3) has large outer loading. This is showing that the time as a member of group and the time to produce slap mendong has large contribution in reflecting expertise and experience variable (X1). On the variable capital (x2) above, it can be explained that all items of the variable capital (X2) has a p-value less than 0.05 . So, it can be said that all indicators is significant. Indicator tool for the production of processed pandanus leaves them (x 2.1 in) has the value of the outer most loading. This is indicating that large contribution for all indicators toward capital variable (X2) is measured by indicator of tools to produce slap mendong (x2.1).

On the motivational variable (X3) above, it can be explained that all the constituent items variable motivation (X3) have had a p-value less than 0.05 . So it can be said that all indicators is significant. Indicator of profit obtained as a member (x 3.2) have a value of outer loading sleds. This indicates that the greatest contribution of Motivational Variables (X3) measured by the indicators of the advantage obtained as a member (x 3.2). On a variable productivity (Y1) above, it can be explained that all the constituent items variable productivity (Y1) has had a p-value less than 0.05 . So it can be said that all indicator is significant. An indicator of the quantity produced in one day (y 1.1) has a value of outer most loading. This indicates that the greatest contribution to the Variable productivity ( $\mathrm{Y} 1)$ measured by the indicators of the quantity produced in one day (y1.1) the test results on line direct influence Coefficient . After doing validity, reliability and consistency indicator to prepare latent variable (outer model) comply with, the next step is to test structural inner model. Hypothesis testing is done with test $t$ on each line a direct influence. The direct influence is said to be significant if the test results obtained by the $\mathrm{p}$-value $<0.05$.

The following table presents the results of testing the hypothesis of direct influence.

Table 6. Path coefficient test results influence directly

\begin{tabular}{lccccc}
\hline \multicolumn{1}{c}{ exogenous variable } & Endogenous variable & Path Coefficient & T-Statistic & P-Value & Remaks \\
\hline Expertise and experience (X1) & & 0.231 & 2.040 & 0.043 & Significant \\
Capital (X2) & Productivity (Y1) & 0.252 & 2.887 & 0.004 & Significant \\
Motivation(X3) & & 0.083 & 0.769 & 0.443 & Non-Significant \\
Expertise and experience(X1) & & -0.266 & 6.852 & 0.000 & Significant \\
Capital(X2) & \multirow{2}{*}{ Welfare (Y2) } & 0.823 & 16.266 & 0.000 & Significant \\
Motivatgion(X3) & & 0.133 & 2.025 & 0.044 & Significant \\
Productivity(Y1) & & 0.293 & 5.737 & 0.000 & Significant \\
\hline
\end{tabular}

Results of hypothesis testing the direct influence can also be seen in the image path diagram as follows Remarks: 
$\mathrm{s}=$ significant on alpha 0,05 and $\mathrm{ns}=$ not significant

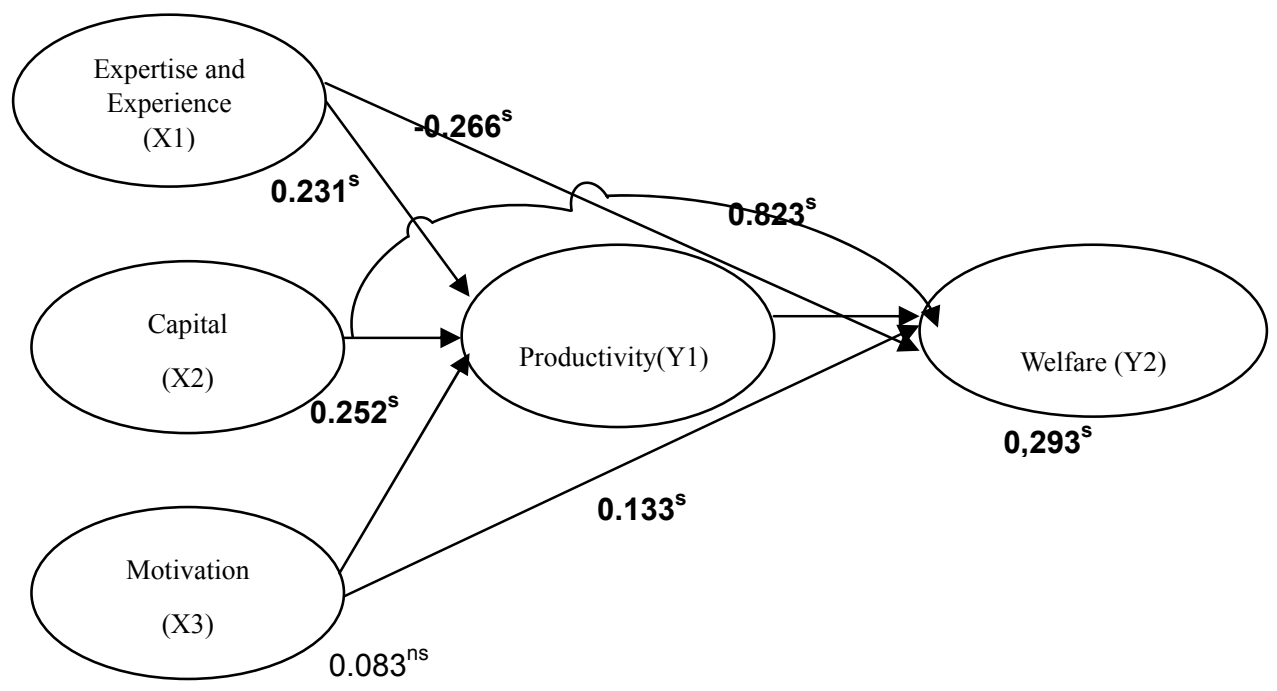

Figure 3. Diagram of the path coefficient test results influence directly

From table 6 and Figure 3 above to see that line direct influence between expertise and experience (X 1) to productivity (Y1) has path coefficient 0,231 with $\mathrm{p}$ value 0.043 . The expertise and experience of the variables (X 1) provides a significant and positive influence on productivity (Y1). The higher the skill and experience of craftsmen has direct impact to craftsmen slap mendong.

The direct influence of capital (x 2) to productivity (Y1) have a coefficient of 0,252 path with a p-value of 0,004. The variable capital (X 2) provides a significant and positive influence on productivity (Y1). The higher the capital owned by craftsman, the higher craftsmen increase their productivity.

The influence of direct motivation (X 3) to productivity (Y1) have a coefficient of 0,083 path with a p-value of 0,443. Motivational variables (X 3) does not give significant impact to productivity (Y1). Path coefficient variable capital (x 2) is larger than the other variables showed that the capital (x 2) the dominant effect directly against productivity (Y1). The direct influence of the expertise and experience of the Variables (X 1) against Welfare (Y2) have a coefficient of path-0,226 with a p-value of 0.000 .

Expertise and Experience Variables (X1) provide significantly and adversely Welfare (Y2). The expertise and experience of craftsmen slap mendong high rushes actually decrease the revenue. This happens due to the increase of expertise and experience (without producing) takes time and costs. So it can be reduced the revenue and decrease the welfare of craftsmen.

Pathways of influence between capital (X2) on Welfare (Y2) has a path coefficient of 0.823 with a p-value of 0.000 . Variable Capital (X2) provide a positive and significant influence on Welfare (Y2). Ownership of capital is high, indicating craftsmen who have a high income. Thus, with increasing capital craftsman is capable of improving the welfare of artisans directly. Pathways of influence between motivation (X3) on Welfare (Y2) has a path coefficient of 0.133 with a p-value of 0.044 . Motivation variable (X3) provide a significant and positive effect on welfare (Y2). The higher motivation of craftsmen at work, the higher improving their welfare.

Pathways of influence between Productivity (Y1) of Welfare (Y2) has a path coefficient of 0293 with a p-value of 0.000. Variable Productivity (Y1) provide a positive and significant influence on Welfare (Y2). The higher productivity of craftsmen slap rushes, it will have an impact on increasing the welfare of artisans directly.

Pathways of influence between Productivity (Y1) of Welfare (Y2) has a path coefficient of 0293 with a p-value of 0.000. Variable Productivity (Y1) provide a positive and significant influence on Welfare (Y2). The higher productivity of craftsmen slap rushes, it will have an impact on increasing the welfare of artisans directly. In addition, it also calculated the effect of the total, to investagate independent variables which are the most powerful influence on the dependent variable. Following the total effect of the independent variables: 
Table 7. Effect hypothesis testing results total inner model

\begin{tabular}{cccccc}
\hline Variable & Endogenous variable & Total Effect & T-Statistic & P-Value & Remarks \\
\hline Expertise and experience (X1) & & -0.198 & 3.899 & 0.000 & Significant \\
Capital (X2) & Welfare (Y2) & 0.896 & 16.766 & 0.000 & Significant \\
Motivation (X3) & & 0.158 & 1.780 & 0.077 & Non-Significant \\
Productivity (Y1) & & 0.293 & 5.737 & 0.000 & Significant \\
\hline
\end{tabular}

The magnitude of the total effect of variables can also be seen in the following figure.

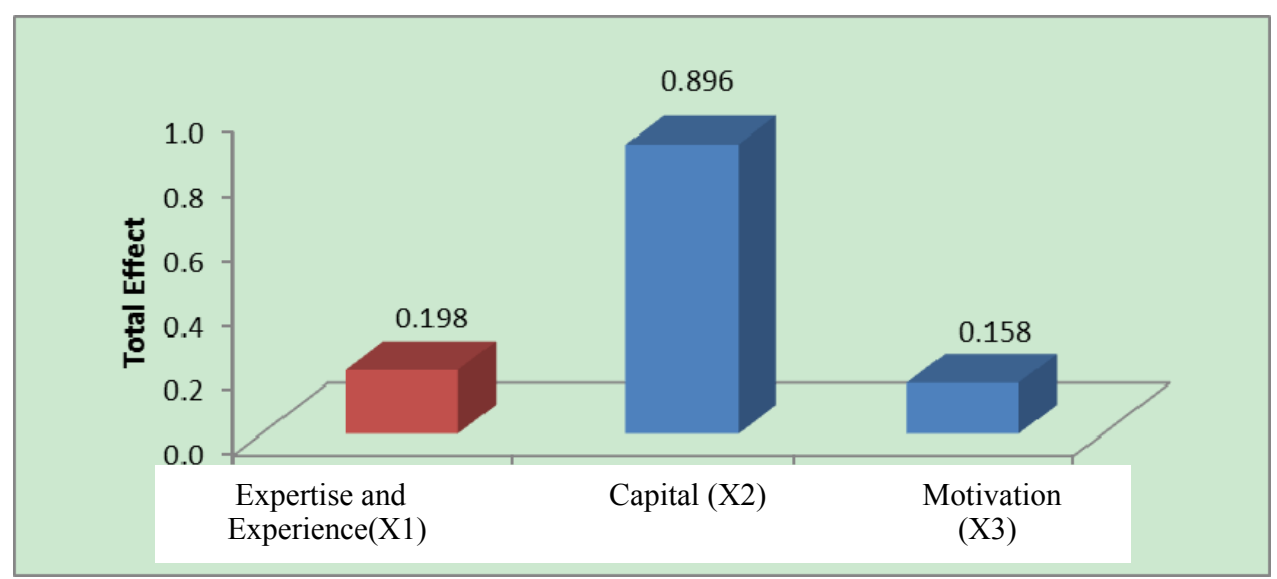

Figure 4. The magnitude of influence in total independence variable to welfare (color red is drawing negative influence)

Based on Table 7 and Figure 4 above, it can be explained that the expertise and experience variables (X1) has a total effect of -0.198 , Variable Capital (X2) has a total effect of 0.896 , and the motivation variable (X3) has a total effect of 0.158 . The total effect of variable capital (X2) is greater than the other independent variables. This indicates that the variable capital (X2) has the strongest effect (dominant) against Welfare (Y2).

\section{Discussion and Results}

Based on the results of data analysis above, it can be given the following discussion that the influence of expertise and experience to the Productivity and Welfare Craftsmen Slap Mendong can be explained as follows:

1) Based on the results of data analysis, it is shown that the variable expertise and experience provide direct influence significantly and positively to productivity craftsmen slap mendong. To improve the productivity of craftsmen slap mendong, it can be done by increasing the expertise and experience of craftsmen. However, if the total effect of a variable in terms of the expertise and experience of well-being, indicated that the skills and experiences precisely a negative impact on welfare. This suggests that in order to improve the welfare of craftsmen, it is no need to increase the skills and experience of craftsmen. Expertise is defined as someone who has a certain level of skill or knowledge in a particular subject which is derived from training or experience (Murtanto, 1999). Thus, expertise is defined as the existence of knowledge about a particular environment, an understanding of the problems that arise in the environment and skills to solve these problems. The craftsmen slap mendong has expertise to make slap for along time. Based on the discussion with them, they revealed that making slap mendong for many years. Therefore, it is not necessary to train them to use equipment, but rather to modernize their equipment to be efficient. According to Simanjuntak (1985) productivity implies philosophical and quantitative. Philosophically productivity implies a view of life and the mental attitude of always trying to improve the quality of life. In quantitative, productivity is a comparison between the results to be achieved (output) with the overall resource (input) which is used per unit time. In Blayu village, the research found that the relationship between expertise and experience has a liitle impact to the craftsmen as long as there are no improvement on machines mechanism. The craftsmen need capital and new equipment to support their productivity.

2) Capital Effect on Productivity and Welfare of craftsmen Slap Mendong 
Based on the results of the analysis of research data, it is indicated that capital variables significantly influence direct and positive impact on the productivity of craftsmen slap mendong. To increase the their productivity, it can be done by increasing the capital. Likewise, if the terms of the effect on the welfare of the total capital variables, indicated that the capital have a positive influence on well-being. This suggests that in order to improve the welfare of craftsmen, it can be done by increasing capital, primarily in terms of aspects of the production equipment slap mendong. This result of this study is in line with conclusion of widiiastuti research. According Widiastuti (2012) the conclusion of her study indicated there is no influence between labour productivity and education levels of workers on the welfare of the family. Welfare is the measuring point for a society that has been in a prosperous condition. Welfare is realized so that the citizens can live a decent and able to develop themselves. Therefore, they can perform their social function properly, if prosperous society means that society of prosperity. Measuring of productivity according muchdarsyah Sinungan (2008) stated that working hours and working days, due to labour productivity can be calculated by dividing expenditures by the number of hours used or someone working hours. Measuring productivity using the work of someone in the form of wages, where the magnitude of the wage is determined by the magnitude of the sacrifices made by workers in the form of working hours.

3) Effect of Motivation on the Productivity and Welfare of craftsmen Slap Mendong

It is indicated that the motivational variables did not significantly influence direct and positive impact on the productivity of craftsmen slap mendong. Whereas, if the terms of the effect of motivational variables on the total well-being, indicated that motivation have a positive influence on well-being. This suggests that in order to improve the welfare of craftsmen, it can be done by providing support to motivate craftsmen. How strong is the motivation of the individual will determine much of the quality of the display of behaviour, both in the context of learning, work and in their live. The study of motivation has long had a special attraction for educators, managers, and researchers, mainly associated with the interests of effort performance of workers. Motivation plays an important role in building the spirit and mentality of the craftsmen slap mendong. A good leader can provide a good motivation for sure make these respected leaders and there is a special feeling inside workers to continue to do better than that achieved now and will increase performance and the quality of work. Factors that are categorized as motivational factors include the work of a person, achieved success, growth opportunities, career advancement and recognition of others. Otero (2003) stated that the level of effort exerted in a business endeavor is directly related to the individual's initial state of need for success. While many studies have analyzed the effects of employee motivation on the productivity of the firm, researchers have not determined the effects that motivation to start-up a microenterprise could have on the efficiency of the firm.

\section{Conclusion}

When it comes to empower craftsmen slap mendong, our result suggest that to increase productivity, it is needed focus on giving working capital mainly for provision of appropriate equipment as aid package slap mendong to be efficient in production. In another hand, Providing motivation to the craftsmen to increase their production has positive affect to increase craftsmen welfare. Whereas program to encourage expertise and experience to enhance craftsmen welfare is not connected. The basic argument is that the craftsmen slap mendongs have long tradition started the business. Those who are starting to be craftsmen slap mendong based on 'family tradition' are more technically efficient than those who started due to the lack of employment opportunities. Therefore, Empowerment policy should be prepare by government is that welfare policy should reflect on two things. First, to strengthen motivation to increase their production by modernization their equipments in order create high performing people drive business success. Second, It is needed capital assistance for increasing productivity by using cooperative approach.

\section{Acknowledgments}

The corresponding author are gratefully to thank the head of Research institutions and community development of Brawijaya University by granting me the opportunity to do this research.. I also would like to thank the Dean of faculty of Fisheries and Marine Science whose help me for to accelerate my research.

\section{References}

Astriana, W. (2012). Analysis of the relationship between Labor Productivity and Worker Education Level Against Family Welfare in Central Java in 2009. Analysis Journal of Development Economics.

Cabrita, M., \& Bontis, N. (2008). Intellectual capital and business performance in the Portuguese banking industry. Int. J. Technology Management, 43(1-3), 212-237. http://dx.doi.org/10.1504/IJTM.2008.019416

Card, D. (2006). The Challenge of Productivity Measurement. Procedings: Pasifc Northwest Software Quality Conference, 2061 (3), 25-31. 
Corsetti, G., Pesenti, P., \& Roubini, N. (1999). What the caused the Asian currency and financial crisis? Japan and the World Economy, 11, 305-373. http://dx.doi.org/10.1016/S0922-1425(99)00019-5

Fatih Fellan Abdillah, Surjono, Gunawan Prayitno. (2010, December). Development of Agro Industry Handicrafts Center Mendong Kabupaten Malang With local economic development approach. Journal of Urban and Regional Planning, 2(2).

Hajiha, Z., \& Hasanloo, S. (2011). An Empirical Study of the Relationships among Human Capital Value and Profitability and Market Value: Comparison of Knowledge-Based Industries and NonKnowledge-Based Industries. Asian Journal of Business and Management Sciences, 1(3), 105-114.

Hikmasari, R., Muhaimin, A. W., \& Setiawan, B. (2013, April). Technical Efficiency of Mina Mendong Farm Using Stochastic Production Frointer Approach (Case Study in Blayu and Wajak Village, Wajak District, Malang Regency). Habitat Journal, XXIV(1).

Jogiyanto, \& Abdillah, W. (2009). Concepts and Applications of PLS (Partial Least Square) for Empirical Research. BPFE, Yogyakarta.

Maditinos, D., Chatzoudes, D., Tsairidis, C., \& Theriou, G. (2011). MIBES Transactions, 5(1), 58-72.

Muchdarsyah, S. (2008). Productivity What and How. London: Earth Literacy.

Murtanto. (1999). Identifying Characteristics of Audit Expertise. Indonesian Journal of Accounting Research, 2(1), 37-51.

Otero, R., \& Pagan, J. A. (2003). Motivation, Learning-by-doing and Technical Efficiency in The Micro Enterprise sector in Mexico Working paper $\neq 2002-18$, October 2003, Center of Border Economic Studies, The University Texas-Pan America.

Rafiei, M., Feyzi, T., \& Azimi, H. (2011). Intellectual capital and its effect on economic performance: A Case Study in Iranian Automotive Industry. Journal of American Science, 7(6), 497-507.

Raz, A. F., Indra, T. P. K., Artikasih, K. D., \& Citra, S. (2012, October). Global Financial Crisis and Economic growth: Analysis of East Asian Economies. Bulletin of Monetary Economics and Banking.

Seitte, Y. (2012). Decision Making Analysis for Mendong Farmers on Mendong Bussiness Unit. Essay. Faculty of Agricultural, Brawijaya University.

Simanjuntak, P. J. (1985). Introduction to the Economics of Human Resources. Jakarta: LP - FE, UI.

Solimun, et al. (2006). Structural Equation Modeling Approach PLS and SEM, Application Software SmartPLS and Amos 6. Faculty and Graduate Programs. Brawijaya University, Malang.

Tobias, R. D. (n. d.). An Introduction to Partial Least Square Regression. SAS Institute Inc., NC.

\section{Copyrights}

Copyright for this article is retained by the author(s), with first publication rights granted to the journal.

This is an open-access article distributed under the terms and conditions of the Creative Commons Attribution license (http://creativecommons.org/licenses/by/3.0/). 